\title{
PRACTICE-BASED SEGMENTATION: TAXONOMY OF C2C CO-CREATION PRACTICE SEGMENTS
}

This is an author's version of manuscript accepted for publication in the International Journal of Contemporary Hospitality Management on 5th July 2019.

Please refer to: Rihova, I., Moital, M., Buhalis, D. and Gouthro, M. B. Practice-based segmentation: Taxonomy of $\mathrm{C} 2 \mathrm{C}$ co-creation practice segments. International Journal of Contemporary Hospitality Management, DOI: 10.1108/IJCHM-01-2018-0096

\section{Structured Abstract:}

Purpose: This paper explores and evaluates practice-based segmentation as an alternative conceptual segmentation perspective that acknowledges the active role of consumers as value co-creators.

Design/methodology/approach: Data comprising various aspects of customer-to-customer co-creation practices of festival visitors were collected across five UK-based festivals, using participant observation and semi-structured interviews with naturally occurring social units (individuals, couples and groups). Data were analysed using a qualitative thematic analysis procedure within QSR NVivo 10.

Findings: Private, Sociable, Tribal and Communing practice segments are identified and profiled, using the interplay of specific subject- and situation-specific practice elements to highlight the 'minimum' conditions for each $\mathrm{C} 2 \mathrm{C}$ co-creation practice. Unlike traditional segments, practice segment membership is shown to be fluid and overlapping, with fragmented consumers moving across different practice segments throughout their festival experience according to what makes most sense at a given time.

Research limitations/implications: Although practice-based segmentation is studied in the relatively limited context of $\mathrm{C} 2 \mathrm{C}$ co-creation practices at festivals, the paper illustrates how this approach could be operationalised in the initial qualitative stages of segmentation research. By identifying how the interplay of subject- and situation-specific practice elements affects performance of practices, managers can facilitate relevant practice-based segments, leading to more sustainable business. 
Originality/value: The paper contributes to segmentation literature by empirically demonstrating the feasibility of practice-based segments and by evaluating the use of practicebased segmentation on a strategic, procedural and operational level. Possible methodological solutions for future research are offered.

Keywords: segmentation; qualitative segmentation; co-creation; social practices; festival visitation

Article classification: Research paper 


\section{PRACTICE-BASED SEGMENTATION: TAXONOMY OF C2C CO-CREATION PRACTICE SEGMENTS}

\section{Introduction}

Segmentation as one of the most fundamental concepts in marketing has been examined for some time (Dibb and Simkin, 2001). Researchers have sought insights into how heterogeneous consumers with a range of characteristics, attitudes and behaviours can be grouped into homogenous groups, to identify and satisfy product/service preferences of a chosen prospective consumer segment. Segmentation encourages consumer orientation by aligning with consumers' needs; it helps to detect and exploit new market opportunities; leads to a better ability to predict consumer behaviour and foster desired behavioural change; and, facilitates more efficient allocation of organisational resources through better understanding of the market (Kotler and Keller, 2012).

Traditional marketing tends to view segmentation as a crucial tool in a three-step segmentation-targeting-positioning (S-T-P) strategy (Kotler and Keller, 2012). This objective continues to dominate; however, recent marketing literature highlights the need for segmentation research to acknowledge a growing complexity in the marketplace, with consumer agency becoming a crucial consideration. The concepts of value co-production and co-creation (Etgar, 2008; Prahalad and Ramaswamy, 2004), and the service-dominant (S-D) (Vargo and Lusch, 2004) and customer-dominant (C-D) logics in marketing (Grönroos and Voima, 2013; Heinonen et al., 2013), emphasise dialogical exchanges between marketers and consumers and within consumer communities. The C-D logic in particular suggests that value co-creation takes place outside the service provider's direct scope of influence (Heinonen and Strandvik, 2015), including in social encounters between consumers in socially-dense, experiential contexts such as tourism and hospitality (Kim et al., 2019; Luo et al., 2019; Reichenberger, 2017; Rihova et al., 2018).

The increasing focus on consumers as active value co-creators means that traditional segmentation goals and methodologies may no longer be relevant. While searching for valid criteria for selecting segments, research has neglected more fundamental issues of who we should segment and why. Researchers are starting to explore the consumption patterns of existing customers; i.e. customer-induced as opposed to market-induced segmentation (Sausen et al., 2005). But despite highlighting concepts such as customer lifetime value, retention and loyalty (Kim et al., 2006; Weinstein, 2002), and the use of alternative 
segmentation bases such as person-activity (Allenby et al., 2002) and participation in service production (Chen et al., 2017), traditional segmentation falls short of addressing the fluid nature of social consumption and value co-creation.

As Holttinen (2010) notes, co-creating consumers engage in a number of practices according to what makes sense at a particular point in time. They move from one segment to another in a somewhat inconsistent manner. This ontological shift toward practices as opposed to individual consumers makes employing traditional segmentation methods difficult. Holttinen's (2010) argument, which to our knowledge has not been examined in detail, provides a theoretical starting point for this study. In order to acknowledge the co-creation turn in marketing and to address issues with traditional segmentation in the new co-creation worldview, we tentatively explore and evaluate practice-based segmentation as a potential conceptual alternative to more traditional segmentation approaches. Customer-to-customer (C2C) co-creation practices of festival visitors are used as an empirical context for the study of practice-based segmentation.

\section{Theoretical background}

\subsection{Basic tenets of market segmentation}

Consumers vary from one another in a number of ways, effectively forming in excess of 7 billion segments (Snellman, 2000). This complexity can be reduced by seeking homogeneity within segments with respect to the firm's marketing objective and availability of resources (Kotler and Keller, 2012). Segmentation research has therefore prioritised the identification of segmentation bases. Categories such as demographics, psychographics, benefits, emotions, attitudes, and values are used as a priori segmentation bases to identify customer segments with different degrees of price elasticity and to help marketers pinpoint a suitable target market (Wedel and Kamakura, 2000).

But while segment determination using such a priori bases ensures within-segment similarity, it may not mean a consistent within-segment customer response (Hoek et al., 1996). Demographic and psychographic variables are often combined with a posteriori or post hoc approaches that focus on consumers' attitudes, motivation, and purchasing/use behaviours (Wedel and Kamakura, 2000). This approach enables more accurate descriptions of previously unknown consumer segments, making targeting strategies more effective. 
Researchers have used such criteria to segment tourists (Atadil et al., 2017); diners (Chen et $a l .$, 2017), culinary festival visitors (Viljoen et al., 2017); and retail shoppers (Angell et al., 2012).

Data analysis techniques correspond with segmentation criteria focus and include various types of cluster analyses, factor analyses, discriminant analysis, and Chi-square Automatic Interaction Detection (CHAID) (for a detailed discussion, see, e.g., Dolnicar, 2008). As Snellman (2000, p.29) observes, "researcher after researcher tried to show relationships between different variables and buying behaviour." But scholars disagree on the most suitable technique in a given situation, resulting in a disconnect between segmentation research and its practical implementation (Hoek et al., 1996; Quinn and Dibb, 2010).

\subsection{Customer-induced segmentation and value co-creation}

Quinn and Dibb (2010) argue that the emphasis on segment identification and profiling has been informed predominantly by managerial and operational agendas. But less attention has been given to segmentation for strategic purposes. Sausen et al. (2005) suggest that strategic objectives can be addressed by employing a customer-induced segmentation approach. Among other objectives, this approach addresses customer retention and proposes segmentation strategies based on loyalty and relationship management (Sausen et al., 2005). Customer-induced market segmentation therefore emphasises existing consumer base and disaggregated consumers (Snellman, 2000).

The shift in segmentation objects is underpinned by recent marketing thought developments. For example, post-modern perspectives advocate segments of one (Dibb and Simkin, 2001) and also assume that consumers move among and between different consumer tribes, demonstrating the fluid nature of segment membership (D’Urso et al., 2016; Goulding et al., 2013). Marketers traditionally viewed segments as stable, with segmentation research involving one-off studies (Hoek et al., 1996). With innovative and dynamic use of real-time data this issue is increasingly being addressed, though the stability assumption still prevails in segmentation research (Simkin, 2016). But even though customer-induced segmentation research can reveal different motivational conditions and attitudes of existing consumers, it may be unable to capture the wider context in which consumption takes place.

With the proliferation of the co-production (Etgar, 2008) and co-creation (Prahalad and Ramaswamy, 2004) concepts, marketing has acknowledged the active role of consumers in the service exchange process. Proponents of the S-D logic in marketing (Vargo and Lusch, 
2016, 2008) suggest that businesses must support customers' value co-creation through services and resources, as it is the customer who determines what is valuable. Competition centres on the provision of personalised co-creation experiences (Prahalad and Ramaswamy, 2004), with consumers' access to tools, resources and information enabling the co-creation of experiences with firms. More recent S-D logic research views value as being co-created in a networked context; value depends not only on the individual actors and their resources but also on the context (including the social context, norms, symbols, laws and practices) in which they operate (Edvardsson et al., 2011; Horbel et al., 2016; Vargo and Lusch, 2016). In a separate stream of research, authors aligned with the Customer-Dominant (C-D) logic in marketing propose that firms should facilitate co-creation relevant to consumers themselves (as opposed to co-creating value linked to the company's offering) (Heinonen et al., 2013). CD logic proponents further argue that customers' co-creation may take place outside the firm's scope of influence (Heinonen and Strandvik, 2015). This is relevant in tourism and hospitality settings, as $\mathrm{C} 2 \mathrm{C}$ co-creation may generate social and cultural value that goes beyond the immediate service experience (e.g., Rihova et al., 2018). In a C2C context, consumers' co-creation may even threaten the firm, for example through negative word-ofmouth in both physical and virtual spaces (Reichenberger, 2017).

The growth of the service economy, organisational development and the increasing emancipation and fragmentation of consumers in the marketplace have meant that segmentation research needs to emphasise customers' co-creation of value, which could ultimately lead to increased competitive advantage and thus higher levels of profitability and loyalty (Chen et al., 2017; Firat and Shultz, 1997 p.197). With marketers' desire to design value offerings to facilitate consumers' co-creation processes, the role of segmentation shifts from attracting profitable prospects to retaining happy co-creators.

A number of authors (Chen et al., 2017; Grissemann and Stokburger-Sauer, 2012; Tu et al., 2018) discuss the benefits of adopting a co-creation or co-production approach [or a mixture of both, as per Chathoth et al. (2013)] in tourism and hospitality contexts. For instance, Chathoth et al. (2014) argue that high-end hotels can gain competitive advantage by facilitating a consumer-oriented co-creation approach. The authors do not explicitly address segmentation, but note that by analysing relevant co-creation segments, hospitality firms can address changing customer needs. Chen et al. (2017) acknowledge the importance of consumers as co-creators in segmentation research. They use level of participation in cocreation as a basis for identifying four distinct segments, profile these in terms of 
demographics, attitudes and behaviours, and evaluate the relationship between the segments and positive service outcomes. Dowell et al. (2019) present a taxonomy of segments based on cultural value co-created of attendees at Welsh cultural festivals. The authors highlight the cocreation of value as a crucial development in the context of segmentation, but do not go beyond identifying various dimensions of cultural value as alternative segmentation bases. The methodological foundations of segmentation research are increasingly being challenged as a result of the recent thought developments in marketing. Allenby et al. (2002) note that 'revealed market data' in segmentation studies are inadequate in describing the mechanisms that govern consumer behaviour, as they fail to focus on the motivating conditions that lead people to the tasks and interests in their lives. A posteriori or post-hoc (Wedel and Kamakura, 2000) behavioural segmentation and qualitative techniques exploring the actions and behaviours of existing consumers play an increasingly important role, for example to serve as a basis for developing segments and then validating or refining them using quantitative approaches (Chen et al., 2017; Dolnicar, 2008). Techniques such as Latent Class (LC) analysis are useful for new product development, positioning and repositioning, as they help to understand how existing customers group together based on their needs and other attributes, linking these to behaviours such as frequency or type of service usage. Probability modelling is used to assign customers to clusters, while customers may belong to more than one cluster (Bond and Morris, 2003). But behavioural segmentation tends to focus only on buyer behaviour patterns (usage, price sensitivity, benefits and utilities), and may not necessarily account for social consumption and $\mathrm{C} 2 \mathrm{C}$ co-creation.

Fuzzy set qualitative comparative analysis [Fs/QCA] (Ragin, 2008) may be useful in such context. The methodology examines theoretically guided selection of cases and combinations of member attributes in order to discover how causes lead to outcomes (e.g. high performance in high-performing organisations) (Fiss, 2011). The nature of casual relationships cannot be determined a priori and the method does not rely on probability distribution and Boolean algebra and algorithms to identify a reduced set of causal combinations that lead to a given outcome. As an accepted analytical method in social sciences designed for qualitative case studies with small samples, Fs/QCA could represent a suitable methodological approach for customer-induced segmentation research that takes into account the complex contexts in which consumers co-create value with companies as well as with each other $(\mathrm{C} 2 \mathrm{C}$ cocreation). 


\subsection{A theoretical framework: segmentation of social practices}

The above approaches represent useful tools to increase the usability and validity of segmentation (Dibb and Simkin, 2001). But the established qualitative and conceptual steps in identifying suitable segments in the context of customer co-creation (and social consumption in particular) are still relatively under-developed. Social practice theory has been highlighted by C-D logic scholars as a fruitful lens through which customers' co-creation may be viewed (Holttinen, 2010). We therefore present the practice-based approach to segmentation as a tentative theoretical framework for addressing the above issues. (For a detailed review of social practices and how the practice-based approach has been used in recent marketing studies, see Kjellberg et al., 2018).

Much of practice-based research in the marketing field draws on the works of Schatzki (1996) and Reckwitz (2002), with practices defined as "embodied, materially mediated arrays of human activity centrally organized around shared practical understandings" (Schatzki, 2001, p.11). Schatzki (1996, p.91) views practices as contexts and situations directed by rules/norms and teleoaffective structures within which consumers act. Rules are often presented in externally determined explicit or implicit formulations of what to do in a given situation, while teleoaffective structures (consisting of ends, purposes, emotions and beliefs) direct consumers' engagement in terms of what makes best sense to do in the specific practice (Schatzki, 2001, p.100).

A number of empirical practice-based studies (Echeverri and Skålén, 2011; McColl-Kennedy et al., 2012; Russo-Spena and Mele, 2012; Schau et al., 2009) describe practice elements in various ways, though generally they can be conceptualised as follows: the practitioner (consumer) as the subject in practices carries out some bodily actions that the practice requires, drawing on relevant resources (e.g. a set of particular skills or social networks). This happens within the material confines of physical environments and symbolic meaning structures, which together represent the practice performances context. These categories can be summarised as actions and subject-and situation-specific practice elements, and their combinations determine how a practice is carried out. Shared meaning structures (for example, rules of social engagement in formal situations such as a graduation) provide stability in practice performance. A practice may change if its crucial elements are altered, for instance by introducing new rule structures or changing the physical context. 
Crucially, consumers engage in those practices that are valuable to them; value co-creation is therefore tied to a specific practice rather than to a product or service offering (Holttinen, 2010). A small number of empirical studies address the co-creation of value through practices, highlighting the needs and characteristics of practice-based segments among existing consumers. For example, authors shed light on social practices relating to baseball spectatorship (Holt, 1995); elite football (Yngfalk, 2013); fitness clubs (Cassop Thompson, 2012); higher education institutions (Giraldo Oliveros, 2015); forest-based tourism (Rantala, 2010); Airbnb host/guests encounters (Camilleri and Neuhofer, 2017); online social mediabased causes (Sorensen and Drennan, 2017); and, brand communities (Schau et al., 2009). But the above studies do not explicitly and systematically address the interplay of practice elements that could help marketers facilitate specific value-creating practices, or indeed, evaluate a practice-based perspective as a viable segmentation approach.

Holttinen (2010, p.105) argues that firms can develop superior value propositions by identifying practice segments and describing how value is created in them, using practice elements as bases for practice-based segments. But the author does not specify which elements play the most important role in influencing consumers' involvement in practices and how such segmentation bases could be researched and operationalised. Building on Holttinen's (2010) proposition, we therefore argue that social practices, rather than consumers or markets, should be the primary unit of analysis in segmentation studies that emphasise a customer-induced segmentation perspective. In order to explore and evaluate the viability of the practice-based segmentation approach, we draw on empirical data relating to social consumption and $\mathrm{C} 2 \mathrm{C}$ co-creation at festivals, as outlined next.

\section{Methodology}

Festivals are public celebrations with different themes, such as music and performing arts, literature and storytelling or visual arts (Getz, 2012). They represent an important space in which visitors can bond and spend time with significant others, while engaging in amiable sociability with complete strangers (Wilks, 2011). Genre-specific or themed festivals (e.g., folk music festivals) facilitate a sense of belonging for members of 'consumer tribes' (Mackellar, 2009a). Additionally, festival visitation leads to the emergence of a sense of fellowship and communitas (Turner, 1995) among strangers. These positive social outcomes are valuable for festival organisers, as they can lead to favourable service experience 
perceptions, customer retention and loyalty (Drengner et al., 2012). As such, festivals represent a rich research context for $\mathrm{C} 2 \mathrm{C}$ co-creation research.

A qualitative, interpretive methodology based on naturalistic participant observation and semi-structured interviews was adopted, in line with the social constructionist approach adopted in practice research (Reckwitz, 2002). The sample included five family-friendly UKbased summer festivals that varied in scale (1500-5000 visitors); length (3-5 days); setting (urban/green field festivals across England and Wales); and, genre/theme (food and camper vans; rock music; folk music; storytelling; and, pop music and arts festivals). The five festival cases are referred to in this paper as VanFest, RockFest, Music\&ArtsFest, StorytellingFest and FolkFest, reflecting their main genre.

One of the authors visited each festival and camped alongside the visitors for 3-5 days to ensure immersion. Observation and interview subjects were sampled purposively, with data collection guided by literature on practice elements (Echeverri and Skålén, 2011; McCollKennedy et al., 2012; Russo-Spena and Mele, 2012; Schau et al., 2009) and socialisation in festival contexts (e.g., Mackellar, 2009a; Wilks, 2011). The researcher noted actors' characteristics and their visible actions, features of the physical setting and apparent rule and norm structures within the context. At opportune moments (e.g., when visitors were resting outside their tents or at food outlets) the researcher approached potential interviewees. A total of 52 interviews (20-60 minutes long) with naturally occurring consumer social units (CSUs) were undertaken, comprising 16 interviews with individuals, 22 with couples/pairs, and 14 with groups of three or more. Conversation topics revolved around actions, motivations, resources, physical circumstances and understandings of intangible images and generally accepted rule structures of $\mathrm{C} 2 \mathrm{C}$-oriented social practices. Interviewing couples and groups as opposed to only individuals was important, as it reflected relevant social contexts and relationships between actors (Edvardsson et al., 2011).

Transcripts from the first festival were analysed manually for preliminary themes that could be further explored at subsequent festivals. The complete dataset was then transferred into QSR International's NVivo 10 and analysed using a rigorous five-step thematic analysis procedure (Bazeley, 2007). A broad-brush open coding identified initial descriptive and abstract in vivo categories (Strauss and Corbin, 1990), that reflected the language used by informants (e.g. 'campsite', 'social atmosphere', 'acceptance', 'greeting'). Links and relationships between codes formed the basis of an emerging framework. For example, codes relating to various festival places in which social interactions played out were grouped under 
'contextual factors in co-creation'. Higher-order codes were subsequently coded-on for more detailed sub-categories and through further axial coding, four main categories with up to three levels of sub-categories emerged: 'Co-creation practices', 'Servicescape', 'Subject-' and 'Situation-specific elements'. Literature comparison helped to reduce and abstract from the data, which allowed us to write more accurate summary statements on the content of each sub-category, and to refine the emerging model. At this point we theorised about the relationships between different aspects of social practices with the aid of extensive memo writing and through NVivo's coding matrix function, which revealed patterns in the data; e.g. the prevalence of a particular action within specific contexts.

We strove for trustworthiness through several means. NVivo enables meticulous data management, while within- and cross- case analysis was supported through extensive memo writing (analytical thoughts and observations). In line with previous inductive research (Corley and Gioia, 2004), we subjected emerging concepts to 'peer debriefing'; i.e. representative quotes and summaries were validated by academic experts with festival visitation experience and in-depth knowledge of segmentation, co-creation and/or practice research. The final framework involved identification and description of festival $\mathrm{C} 2 \mathrm{C}$ practice segments, as evidenced in the interplay of symbolic, routinized and goal-oriented actions, and the various subject- and situation-specific practice elements.

\section{Findings and discussion}

\subsection{C2C co-creation practice segments at festivals}

Four distinct practice-based segments were identified through data analysis: Private practices; Tribal practices; Sociable practices; and, Communing practices. These segments reflect to some extent existing literature on $\mathrm{C} 2 \mathrm{C}$ interactions and socialisation in leisure and tourism contexts, though there were some surprising findings, particularly with respect to festival literature. Subject- and situation-specific practice elements helped to identify patterns within practice segments and so aided detailed descriptions of each practice, while acting as 'minimum conditions' for each segment to be feasible (see Figure 1). An overview of practice segments is presented next. 
Figure 1 - Facilitating elements in practice-based segments

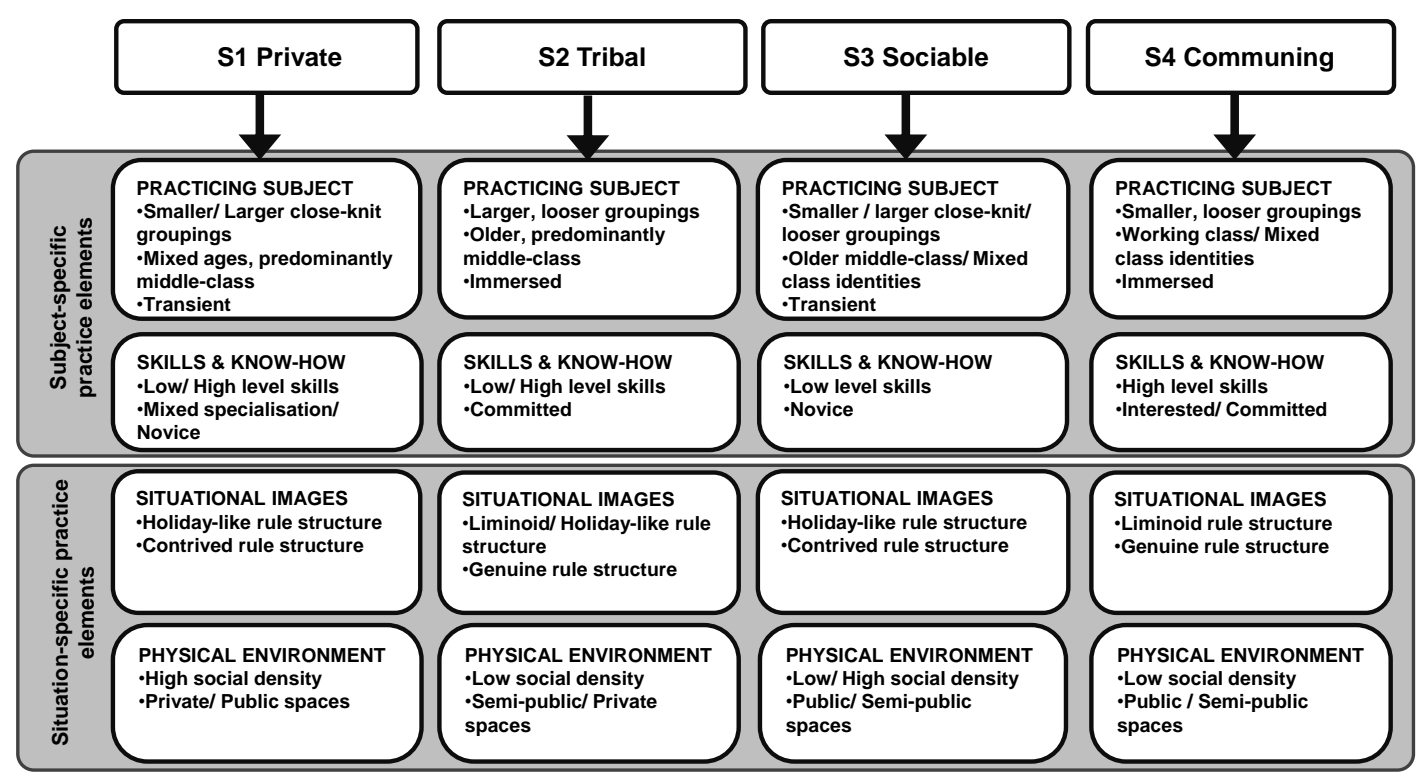

PRIVATE PRACTICES were recognisable among groups of friends, couples or families engaging together in routinized actions such as cooking, eating or sharing tasks (e.g. pitching tents or planning their festival), playing games, listening to music, partying and a getting drunk with each other. For example, Jenna and her friends used the RockFest visit as a bonding opportunity that allowed them to re-enforce established friendships:

Jenna: well, we're not going anywhere we're gonna be still sitting here talking gobshite if you come back in a couple of hours.

Pete: some of us come back in five years and it might even be the same conversation! [All laugh]

An easy-going holiday-like atmosphere existed in the Private practice segment, with previously known customer social units taking time to reaffirm relationships. In some cases, Private practices appeared to take customers into symbolically or physically detached private spaces. Tamara from FolkFest confirmed that many of the visitors she encountered tended to be "in their own personal bubble", while field notes revealed physical detachment with territorial behaviour observed in both larger and smaller groups' camping arrangements:

RockFest field notes (27/05/2012): I approached this group of 7 people as they were sitting in a relatively secluded area of the campsite, below the trees at the right edge of the campsite area. They were sat under a gazebo, which was set up in the middle of an enclosure of four tents in a semicircle and a large van with a colourful windbreaker sheltering the site away from the road and the kids' park just opposite.

References to private practices appear in leisure and tourism contexts where consumption is shared with friends and family. For example, Fu and Lehto (2018) refer to family and friends re-enforcing existing bonds and creating new memories during leisure time. Insulation and 
territoriality are less commonly found in shared consumption contexts, though Tajfel's (1982) concept of in-groups resonates in situations where groups of friends felt in some way threatened by or distanced from the activities of out-group members. Festival literature rarely mentions the notion of insulation or territoriality and, in this respect, the findings are novel.

TRIBAL PRACTICES involved exchanges among tribal community members, and membership expressions by exhibiting symbols and artefacts (e.g. band t-shirts and tattoos). Symbolic tribal structures emerged where customers identified with a special interest genre, brand, lifestyle or object of consumption, in line with what Belk (2010) terms 'pseudokinship'. For example, FolkFest attendees wore clothes and attire that was indicative of a folk music community style:

FolkFest field notes (24/08/2012): [...] faded jeans, wellies, old but sturdy waterproof coats, leather/ suede hats. The man had a greying beard, and both had pewter tankards attached to their belts in preparation for the evening's ale drinking session.

Verbal expressions of belonging to a community were emblematic of the Tribal practice; e.g. motorhome owners at VanFest talked of their social gatherings as "meets". Exchange of know-how and information was also observed. For instance, Diana highlighted the prevalence of 'jamming' sessions that happened spontaneously around the FolkFest campsite and in dining areas:

Diana: Doing the festivals and coming here is always great, a good inspiration as well... that coming here and seeing all the different types of music and things like that going on everywhere. And you join in and you take a lot away with you.

Tribal practices are evidenced in the festival literature (Begg, 2011; Mackellar, 2009a), and in value co-creation literature that focusses on consumer communities and neo-tribes (e.g., Goulding et al., 2013). Mackellar (2009a) refers to social identity celebration through learning and sub-cultural symbols exchange, while Pongsakornrungsilp and Schroeder (2011) report on football fan communities' co-creative practices of cultural values dissemination.

SOCIABLE PRACTICES were evident in friendly social exchanges involving strangers.

Brief conversations, friendly nods and greetings were exchanged in public spaces around the festival site and campsite, e.g., in shower or bar queues. Experienced festival-goers imparted practical introduction to 'newbies'; for instance Gary from FolkFest often advised strangers on which real ale variety to go for:

Gary: [...] there's so many ales to choose from... 'aaah, which one'...And I chose this drink and it was really nice and they were standing there and - 'Ach, that's really nice, try that', you know, it's really nice and you start talking about that. 
Such actions contributed to a friendly atmosphere, though at times polite sociability could develop into deeper conversations, as highlighted by Pippa from Music\&ArtsFest:

Pippa: You walk past people... with me, it's "hi, good morning! How are you doing?" And then all of a sudden they start with their life story.

C2C interactions literature describes perceived similarity, or homophily (McPherson et al., 2001), as a reason why people often establish contact with others in a social setting. Once connected, consumers engage in autotelic or goal-oriented actions to assist others (Prebensen and Foss, 2011; Reichenberger, 2017), thus contributing to an emerging sense of camaraderie, which Oliver (1999) terms 'social villages'. From a co-creation perspective, sociable practices can be beneficial to the firm; previous research shows that value emerging from customers' 'citizenship behaviours' (e.g. helping, sharing via word-of-mouth) generates a positive service atmosphere and loyalty (Kim et al., 2019; Parker and Ward, 2000).

COMMUNING PRACTICES could be observed in a strong sense of togetherness and spontaneous sociability in shared situations, for instance during performances. The levelling nature of festival-going was communicated through escapist, hedonistic actions (e.g. excessive drinking, dressing up), with festival-goers ignoring social differences and casting away prejudices. For instance, Ginny from RockFest noted how Graham was readily accepted despite walking around in drag-style clothes. In the same festival context, Andy commented on the loose clothing norms at the festival:

Andy: The clothes that they'll be wearing in here, you wouldn't be seen dead in them on the street! It's not designer, it's not this, it's not that, but here, it's the norm. You wear the craziest thing you can get.

The fun-making actions observed in Communing practice resemble Bakhtin's (1968) concept of carnivalesque and Turner's (1995) 'communitas'; unstructured, egalitarian community that emerges in liminoid spaces. Communing is well documented in event and festival studies (Gardner, 2004; Kim and Jamal, 2007; Ryan, 2012) and the findings here resonate with previous research.

As Jane from the FolkFest noted, in communing practice there was a sense of trust among strangers, who relied on the goodwill and active caring of others:

Jane: I have a nine-year old and a twelve-year old that come with us and they're great as well. And people, you look out for each other, you do. Even when you're camping, you look out for each other and it's nice that you can relax as a parent, as well, knowing that the environment you're camping in, people will keep an eye on each other, which is always good as well, you know? 
Looking after each other also involved socially immersive helping (e.g. sharing of resources that went beyond polite advice or help) and prolonged conversations with strangers, with strangers off-loading personal worries and problems. In this sense, festival contexts play an important social supportive function in that people from otherwise excluded groups create connections with others (Rosenbaum, 2008).

The findings indicate that the presence of certain subject- and situation-specific elements was not clear-cut in individual practices. For example, consumer social units (CSUs) with both low and high level of social skill (i.e. openness and confidence vs. shyness) appeared in the Private practices segment, while both Tribal and Communing practice segments were found in contexts with a genuine rule structure (i.e. typical of authentic, grassroots festival spaces) (see Figure 1). This is important from a segmentation perspective; traditionally the contexts within which different segments operate may differ, though the assumption of relatively static segments prevails. The findings show that different segments exist where the same subjectand situation-specific elements are in play, making the use of traditional segmentation criteria less helpful.

Additionally, various CSUs did not necessarily 'stick' to one specific practice in the course of their festival experience but were fragmented in practice performance. For example, folk music enthusiasts Amanda and John came to FolkFest to spend quality time together (Private segment). Once at the festival, they camped in a small private enclosure with a group of friends, with whom Amanda wanted to catch up (Private). The group were part of a folk music club and as regular festival visitors liked to 'jam' with other 'folkies' (Tribal). In the festival food areas they politely conversed with strangers (Sociable) and revelled in the communal atmosphere during performances (Communing). Practice performance by different consumers and at the different festivals was influenced by the interplay of both tangible and intangible subject- and situation-specific practice elements, which together guided actions and interactions and affected how individual consumers and CSUs shifted into and between practice segments. This reflects other S-D logic studies; co-created value depends on specific constellations of actors' resources and the co-creation context (Chandler and Vargo, 2011; Horbel et al., 2016).

An important implication for segmentation is that $\mathrm{C} 2 \mathrm{C}$ co-creation practices at festivals represent a complex and dynamic phenomenon and therefore segmentation approaches cannot be reduced to individuals' observable and reported behaviours, as was done in previous segmentation studies (e.g., Mackellar, 2009b). While the interplay of practice elements means 
that using conventional validation criteria may be problematic in practice-based segmentation approaches, these fluid segments still offer interesting insights that can be operationalised in different ways.

\subsection{Evaluation of the practice-based approach to segmentation}

In the previous section we demonstrated how it is possible to identify naturally occurring $\mathrm{C} 2 \mathrm{C}$ co-creation practices through analysis of symbolic, routinized and goal-oriented actions, and subject- and situation-specific elements that guide these actions. The empirical study serves to explore the use of practices as an alternative conceptual and methodological segmentation basis. In this section we evaluate practice-based segmentation on its own and vis-a-vis traditional segmentation and discuss its applications. Practice-based segmentation is evaluated on multiple levels: (1) strategic level, (2) procedural level and (3) operational level (Tonks, 2009). The strategic level of evaluation considers the main aims and strategic purposes of segmentation research. On a procedural level, practice-based segmentation approach is appraised in terms of the techniques and methods in selecting segmentation variables and bases. On an operationallevel, segment characteristics are evaluated from a managerial perspective. The main differences to traditional segmentation approaches are summarised in Table 1.

STRATEGIC LEVEL EVALUATION is conducted with respect to segmentation's strategic objective and focus. The strategic objective of marketing has shifted in recent decades from 'locking-in' customers through effective marketing mix strategies to understanding organisations' role and purpose in customers' co-creating processes (Grönroos and Voima, 2013; Heinonen et al., 2013; Vargo and Lusch, 2008). Marketing managers increasingly collaborate with their consumer base to co-create more valuable product and service solutions (Vargo and Lusch, 2008); though in some cases consumers' social consumption and cocreation practices may be 'invisible' to the organisation (Heinonen et al., 2013). This is relevant in experiential, socially-dense contexts such as tourism, hospitality and events. As deeper social meanings and values are co-created that customer link to the service experience (Drengner et al., 2012; Rihova et al., 2018), businesses could gain competitive advantage by facilitating those value-forming practices that matter to 'happy co-creators'. This strategic objective is in line with recent emphasis in customer-induced segmentation research on retention and loyalty (Kim et al., 2006; Knox, 1998; Pine et al., 2010; Storbacka, 1997; Weinstein, 2002), and represent a shift toward a more strategic role of segmentation (Hoek et al., 1996; Sausen et al., 2005). 
Table 1 - Comparison of traditional segmentation approaches and practice-based segmentation

\begin{tabular}{|c|c|c|}
\hline Characteristic & Traditional segmentation & Practice-based segmentation \\
\hline \multicolumn{3}{|c|}{ Strategic level } \\
\hline $\begin{array}{l}\text { Strategic } \\
\text { objective }\end{array}$ & $\begin{array}{l}\text { Predicting membership to select most } \\
\text { attractive segments (i.e. which segment } \\
\text { customers belong to based on certain } \\
\text { conditions) }\end{array}$ & $\begin{array}{l}\text { Focus on 'happy co-creators' by } \\
\text { facilitating specific value-forming } \\
\text { practices }\end{array}$ \\
\hline Strategic focus & $\begin{array}{l}\text { Potential (and existing) customers in } \\
\text { market-based segments }\end{array}$ & $\begin{array}{l}\text { Naturally occurring contextualised co- } \\
\text { creation practices in existing (or } \\
\text { potential) consumer-induced segments }\end{array}$ \\
\hline \multicolumn{3}{|c|}{ Procedural level } \\
\hline $\begin{array}{l}\text { Variable } \\
\text { selection }\end{array}$ & $\begin{array}{l}\text { Profiling of customer behaviours, } \\
\text { requirements and expectations within } \\
\text { segments based on variables relevant } \\
\text { to the organisation }\end{array}$ & $\begin{array}{l}\text { Segment profiling based on elements } \\
\text { of naturally occurring practices } \\
\text { (practice elements as indicative } \\
\text { 'minimum' conditions for facilitating } \\
\text { practices) }\end{array}$ \\
\hline Methods used & $\begin{array}{l}\text { Mostly quantitative methods (e.g. } \\
\text { multivariate analysis) to generate } \\
\text { segments of homogenous customers } \\
\text { and determine between-segments } \\
\text { heterogeneity }\end{array}$ & $\begin{array}{l}\text { Qualitative methods (interviews and } \\
\text { observations) with CADQAS- } \\
\text { facilitated analysis and subsequent use } \\
\text { of FsQCA to validate and } \\
\text { operationalise practice segments }\end{array}$ \\
\hline \multicolumn{3}{|c|}{ Operational level } \\
\hline $\begin{array}{l}\text { Segment } \\
\text { relevance }\end{array}$ & $\begin{array}{l}\text { Specific relevant customer segments } \\
\text { selected based on profitability and } \\
\text { other managerial goals }\end{array}$ & $\begin{array}{l}\text { All segments relevant as they reflect } \\
\text { naturally occurring co-creation } \\
\text { practices; focus on practice segments } \\
\text { that generate value for consumers as } \\
\text { well as the firm }\end{array}$ \\
\hline $\begin{array}{l}\text { Segment } \\
\text { membership }\end{array}$ & $\begin{array}{l}\text { Individuals assigned to one segment } \\
\text { only and segment membership viewed } \\
\text { as stable/static (i.e., individuals stay } \\
\text { within their segments, though their } \\
\text { membership may be updated within } \\
\text { short timeframes) }\end{array}$ & $\begin{array}{l}\text { Fragmented consumers belong to any } \\
\text { number of practice segments } \\
\text { (segments overlap) with fluid segment } \\
\text { membership (i.e. individuals may } \\
\text { move between any number of practice } \\
\text { segments or belong to more than one } \\
\text { segment) }\end{array}$ \\
\hline $\begin{array}{l}\text { Segment } \\
\text { effectiveness } \\
\text { and efficiency }\end{array}$ & $\begin{array}{l}\text { Viable segments assessed based on } \\
\text { measurability, accessibility, } \\
\text { substantiality and actionability } \\
\text { (actionable segments that can be } \\
\text { reached by the marketer using } \\
\text { marketing mix tools) }\end{array}$ & $\begin{array}{l}\text { Viable segments assessed on the basis } \\
\text { of sustainability and customers' co- } \\
\text { creation (value is co-created in } \\
\text { customers' social practices and so } \\
\text { sustainable segments may exist } \\
\text { independently of the organisation) }\end{array}$ \\
\hline
\end{tabular}


Furthermore, segmentation research is traditionally aimed at consumer characteristics and responses including behavioural segmentation variables, such as use or benefits sought (Dolnicar, 2008; Sinha and Uniyal, 2005). Individual consumer focus allows marketers to distinguish between consumer markets, and predict a segment's behaviours in relation to marketing inputs. The practice-based perspective is different in its focus on practices as holistic units of analysis. This offers a much more complete understanding of what naturally goes on in specific consumer contexts.

PROCEDURAL LEVEL EVALUATION can be done with respect to variable selection and methods used in traditional vs. practice-based segmentation. Segmentation design and profiling progressed over the years from basic a priori bases to lifestyle and behavioural variables. Marketers have developed multi-layered understanding of consumers in markets thanks to new heuristics, data availability and improved knowledge of segmentation (Simkin, 2016). New information sources such as smartphone and internet data have contributed to this development, with multiple bases processed simultaneously and more frequently. Recent behaviour-based segmentation approaches focus on certain attitudes and expectations of product or service consumption; for example product usage frequency or loyalty-based behaviour (Fu et al., 2017; Weinstein, 2002). But such approaches may be limited in understanding the 'invisible' or 'indirect' nature of C2C co-creation (Heinonen and Strandvik, 2015; Sorensen and Drennan, 2017).

The use of segmentation variables is grounded in the traditional objective to attract and retain profitable prospects (Storbacka, 1997). While this is still relevant, the practice-based approach highlights the need to explore segments based on valuable practices of customers who act and interact in specific consumption contexts. For that reason, the variables used to profile segments are grounded in elements of practices, as opposed to individual customer- or management-led variables. In this study, we draw on a number of practice studies (Echeverri and Skålén, 2011; McColl-Kennedy et al., 2012; Russo-Spena and Mele, 2012; Schau et al., 2009) to conceptualise practice elements in the broader categories of actions and subject- and situation-specific elements, though alternative practice conceptualisations may be used. Actions serve primarily to help identify and profile practice-based segments, while subjectand situation-specific elements represent the 'minimum conditions' for practices to occur and resources to help facilitate specific practices.

Quantitative segmentation approaches are typically used to establish heterogenous segments for predictive marketing planning, with technological developments in segmentation 
methodologies enabling engagement of numerous micro segments simultaneously.

Researchers identify an association (causal or otherwise) between dependent and independent segmentation variables to establish how these correlate in the context of a specific customer or market segment. For instance, Dowell et al. (2019) collected demographic and psychographic details and data relating to value and word-of-mouth behaviour ('value communication'). Through cluster analysis segments of people with similar attitudes towards cultural value dimensions are identified as expressed through attendance at a Welsh cultural event. Those segments represent a snapshot of individuals' value constellations, though do not take into consideration how changing practice elements may alter practice performance or indeed, individuals' value outcomes. Our findings demonstrate that when viewed from a practice-based perspective, consumers in such a segment may attend the event, though may not consistently co-create value in a pre-determined way, as they engage in practices according to what makes sense at the time (Schatzki, 2001).

A mix of qualitative methods should therefore be used to identify and profile practice-based segments in the first exploratory stage, as illustrated in this study. Increasingly sophisticated qualitative analytical techniques, such as matrix analysis and cross-tabulation available via qualitative data analysis software packages (CADQAS), allow for depth of analysis and a good degree of confirmability. Subsequent analysis, patterning, classification and structuring into models can inform quantitative studies to validate segments and measure their relative value, and to provide real-world strategies to develop new and existing audiences. For example, advanced data analytics could capture practice-based segments in digital consumption contexts, with LC and FsQCA techniques utilised to link particular subject- and situation-specific practice elements with desirable value outcomes. Qualitative methods do not allow for generalisable results, and a degree of subjectivity is likely to occur as the researcher plays an important role in interpreting and analysing the data. But as Tonks (2009) notes, content validity may be problematic even in more traditional segmentation studies where the relevance of measured constructs is judged by managers/experts and evaluated in light of the literature. Similar concerns exist in relation to the more recent QCA perspectives (Ragin, 2008).

Lastly, OPERATIONAL LEVEL EVALUATION involves considerations of segment relevance, membership, and effectiveness/efficiency. While traditional segmentation assumes that not all segments are relevant to the organisation and only the most attractive (profitable) segments should be selected, practice-based segmentation contends that there are no irrelevant segments for two reasons. First, the focus of practice-based segmentation is on what is already 
happening. In the context of this study, the four practice segments exist to a varying degree in all five festivals, with patterns identified in the segment profiles evident in all of the settings. This means that certain types of social practices are likely to occur in all festival contexts, regardless of their target market. Second, while some individuals and CSUs participate predominantly in certain practice-based segments, they may change between these in the course of the same consumption experience, as was Amanda and John's case. Therefore, it may prove problematic for marketers to choose one specific (individual) customer segment to focus their efforts on, as 'fragmented customers' (Holttinen, 2010) rarely remain in one segment.

Furthermore, one of the most essential requirements in segmentation research is that there are clear relationships between the dependent and independent variables, thus achieving relative homogeneity within segments and heterogeneity between segments (Tonks, 2009). There should be no overlap across segments, with individuals assigned to one segment only. This criterion is questioned when considering practices as segments. The within-segment homogeneity and between-segment heterogeneity criteria still stand, though only when applied on the practice level, as opposed to the individual consumer level. This study gives examples of multiple practices in festival contexts, as reflected in CSUs engaging in more than one practice concurrently. Therefore, overlap and fluidity are properties of practice-based segments. This addresses one of the main criticisms of traditional segmentation approaches, which is that individuals, once assigned to a segment, remain there (Simkin, 2016). Again, LC and fuzzy set techniques can be utilised to cope with uncertain or vague segment membership before the adoption of more traditional quantitative segmentation techniques (D'Urso et al., 2016).

When assessing the effectiveness and efficiency of selected segments, traditional approaches typically assert that segments should be measurable, discernible, substantial and accessible (Kotler and Keller, 2012). But these criteria may be difficult to apply in a practice-based segmentation approach. The practice segments are discernible in a qualitative sense through observations and interviews with naturally-occurring CSUs, though it may be difficult to estimate segments size due to their fluid nature. The LC and Fs/QCA methodologies described earlier can be used to link specific practice elements to relevant organisational outcomes, looking at social unit size as a basis for estimating segment size. Similarly problematic may be segment profitability, usually measured using value and volume of sales tracked over time (Quinn et al., 2007). The value of practice-based segments could be 
assessed via studies of customer satisfaction and experience, linked to subjective benefits linked to specific practices. The practice-based approach therefore highlights segments that can be content-evaluated based on what matters for customers (Holttinen, 2010), thus creating more realistic and sustainable segments.

\section{Conclusions and implications}

\subsection{Conclusions}

In this paper, practice-based segmentation is explored and evaluated as a conceptual alternative to traditional segmentation approaches. Five UK-based multi-day festivals serve as an empirical context for the study and analysis of $\mathrm{C} 2 \mathrm{C}$ co-creation practices. Using a qualitative observation- and interview-based methodology, we describe four main practice segments: Private, Tribal, Sociable and Communing. We then profile each segment based on various symbolic, routine and goal-oriented actions, and highlight the subject-and situationspecific elements that guide these actions, while representing the 'minimum conditions' for practice performance.

As Wedel and Kamakura (2002, pp.182-183) note, segments are typically determined by the marketing manager's strategic viewpoint of the market. But the increasingly dynamic and fluid nature of segments means that the strategic purpose of segmentation needs to shift toward evolution and sustainability rather than proliferation of products and businesses. Market segmentation as part of an S-T-P process still has a place in organisational agendas. However, modern customers-co-creators are fragmented in that they do not necessarily commit to one practice, or one way of performing a practice. We argue that social practices represent an altogether different starting point for strategic, customer-induced segmentation. They reflect the process of customers' value co-creation as positioned within their own life context, in line with recent C-D logic in marketing discussions (Heinonen et al., 2013; Heinonen and Strandvik, 2015). The next step in segmentation should therefore be to retain what is known about these co-creators, with future segmentation research based on social practices paving the way towards these new agendas.

\subsection{Theoretical implications}


This paper demonstrates how the practice-based approach can be used to shift segmentation's focus to co-creation practices and provides a tentative framework for identification and profiling of segments that reflect consumers' value co-creation. As such, the study contributes to theory in two ways. First, it empirically develops and tests a novel perspective on segmentation by presenting practice-based segmentation as an alternative to established conceptual and methodological approaches. A comprehensive evaluation of the segmentationbased approach vis-a-vis traditional segmentation is presented, focussing on three different levels (as summarised in Table 2): strategic (strategic objective, strategic focus), procedural (variable selection, methods used), and operational (segment relevance, segment membership, segment effectiveness) evaluation. We thus demonstrate that the practice-based approach to segmentation has implications both in terms of the purposes for which segmentation is used, and how it can be operationalised at a managerial level.

The second contribution of the study is that it extends existing research on social practices by demonstrating that these can serve as a segmentation basis. Previous research has considered social practices and $\mathrm{C} 2 \mathrm{C}$ co-creation in various consumption contexts, including events (e.g., Dowell et al., 2019; Mackellar, 2009a; Rihova et al., 2018), tourism (Reichenberger, 2017) hospitality (Camilleri and Neuhofer, 2017), and online communities (Schau et al., 2009; Sorensen and Drennan, 2017). But not much attention has been paid to co-creation practices as a basis for segmentation. Past research had suggested this can be pursued (Holttinen, 2010), but to the best of our knowledge this is the first study to empirically demonstrate that such objective is feasible.

\subsection{Practical implications}

Practice-based segmentation allows for identification of specific intervention opportunities by studying the contexts and 'minimum conditions' in which practices of existing consumer groups occur (Figure 1). Marketers are encouraged to find out what value-co-creating practices their consumers engage in, how these come about, and which controllable/uncontrollable elements shape practices. Organisations can then try to influence the emergence of a specific practice or the ways in which it is performed by highlighting or suppressing controllable subject- and situation-specific practice elements. Looking at the festival context explored in this study, for instance where Private practices are predominantly observed but there are organisational reasons to foster Communing practices, the festival manager can provide more public spaces and market to individuals with higher level social 
skills and festival-going experience. This necessitates different resource deployment strategies, depending on consumer preferences and the extent to which certain practices will naturally occur or not. Marketers therefore need to understand consumption patterns within practice segments, including the mechanisms by which customers combine different practices in the course of their consumption experience.

\subsection{Limitations and future research}

In line with previous qualitative segmentation research that explores the causes and outcomes in small samples (e.g., Fiss, 2011; Skaaning, 2011), this study focuses on C2C co-creation at festivals and as such the empirical findings may be limited to a specific consumption setting. The four practice segments identified in this study are illustrative of $\mathrm{C} 2 \mathrm{C}$ co-creation that naturally occurs in socially-dense, experiential settings, such as tourism, hospitality and events. Future research may undertake further profiling to provide a more nuanced, granular understanding and alternative typologies for other contexts. For example, organisations operating in other service contexts where $\mathrm{C} 2 \mathrm{C}$ encounters are likely to play an important role, such as healthcare, personal fitness or transportation services, may want to pursue our approach in order to facilitate customer loyalty and repeat business. But authors may also extend their focus beyond the context of $\mathrm{C} 2 \mathrm{C}$-oriented practices. Other types of naturally occurring practices (customer-to-service staff) could be included in the data collection procedure. Future research should also attempt to operationalise this approach using fuzzy sets in particular. 


\section{References}

Allenby, G., Fennell, G., Bemmaor, A., Bhargava, V., Christen, F., Dawley, J., Dickson, P., et al. (2002), "Market segmentation research: beyond within and across group differences ", Marketing Letters, Vol. 13 No. 3, pp. 233-243.

Angell, R., Megicks, P., Memery, J., Heffernan, T. and Howell, K. (2012), “Understanding the older shopper: A behavioural typology", Journal of Retailing and Consumer Services, Vol. 19 No. 2, pp. 259-269.

Atadil, H.A., Sirakaya-Turk, E., Meng, F. and Decrop, A. (2017), “Exploring travelers' decision-making styles", International Journal of Contemporary Hospitality Management, Emerald, Vol. 30 No. 1, pp. 618-636.

Bakhtin, M.M. (1968), Rabelais and His World (Translated by Helene Iswolsky), Indiana University Press, Bloomington, IN.

Bazeley, P. (2007), Qualitative Data Analysis with NVivo, SAGE Publications, London.

Begg, R. (2011), "Culturing commitment: serious leisure and the folk festival experience”, in Gibson, C. and Connell, J. (Eds.), Festival Places: Revitalising Rural Australia, Channel View Publications, Bristol, pp. 248-264.

Belk, R.W. (2010), “Sharing”, Journal of Consumer Research, Vol. 36 No. 5, pp. 715-734.

Bond, J. and Morris, L. (2003), "A class of its own: latent class segmentation and its implications for qualitative segmentation research", Qualitative Market Research: An International Journal, Vol. 6 No. 2, pp. 87-94.

Camilleri, J. and Neuhofer, B. (2017), "Value co-creation and co-destruction in the Airbnb sharing economy", International Journal of Contemporary Hospitality Management, Vol. 29 No. 9, pp. 2322-2340.

Cassop Thompson, M. (2012), Customers Value Seeking Practices in Public Sector Health and Fitness Clubs, University of Sunderland.

Chandler, J.D. and Vargo, S.L. (2011), "Contextualization and value-in-context: how context frames exchange", Marketing Theory, Vol. 11 No. 1, pp. 35-49.

Chathoth, P., Altinay, L., Harrington, R.J., Okumus, F. and Chan, E.S.W. (2013), “Coproduction versus co-creation: A process based continuum in the hotel service context", International Journal of Hospitality Management, Vol. 32 No. 1, pp. 11-20. 
Chathoth, P., Ungson, G.R., Altinay, L., Chan, E.S.W. and Okumus, F. (2014), “Barriers affecting organisational adoption of higher order customer engagement in tourism service interactions", Tourism Management, Vol. 42, pp. 181-193.

Chen, S.C., Raab, C. and Tanford, S. (2017), "Segmenting customers by participation: An innovative path to service excellence", International Journal of Contemporary Hospitality Management, Vol. 29 No. 5, pp. 1468-1485.

Corley, K.G. and Gioia, D.A. (2004), "Identity Ambiguity and Change in the Wake of a Corporate Spin-Off”, Administrative Science Quarterly, Vol. 49 No. 2, pp. 173-208.

D’Urso, P., Disegna, M., Massari, R. and Osti, L. (2016), "Fuzzy segmentation of postmodern tourists", Tourism Management, Vol. 55, pp. 297-308.

Dibb, S. and Simkin, L. (2001), "Market segmentation: Diagnosing and treating the barriers", Industrial Marketing Management, Vol. 30 No. 8, pp. 609-625.

Dolnicar, S. (2008), "Market segmentation in tourism", in Woodside, A.G. and Martin, D. (Eds.), Tourism Management: Analysis, Behaviour and Strategy, CAB International, Cambridge, pp. 129-150.

Dowell, D., Garrod, B. and Turner, J. (2019), "Understanding value creation and word-ofmouth behaviour at cultural events", The Service Industries Journal, Routledge, pp. 121.

Drengner, J., Jahn, S. and Gaus, H. (2012), "Creating loyalty in collective hedonic services: the role of satisfaction and psychological sense of community", Schmalenbach Business Review, Vol. 64 No. January 2012, pp. 59-76.

Echeverri, P. and Skålén, P. (2011), "Co-creation and co-destruction: a practice-theory based study of interactive value formation", Marketing Theory, Vol. 11 No. 3, pp. 351-373.

Edvardsson, B., Tronvoll, B. and Gruber, T. (2011), "Expanding understanding of service exchange and value co-creation: a social construction approach", Journal of the Academy of Marketing Science, Springer Netherlands, Vol. 39 No. 2, pp. 327-339.

Etgar, M. (2008), "A descriptive model of the consumer co-production process", Journal of the Academy of Marketing Science, Springer Netherlands, Vol. 36 No. 1, pp. 97-108.

Firat, A.F. and Shultz, C.J. (1997), "From segmentation to fragmentation”, European Journal of Marketing, Vol. 31 No. 3/4, pp. 183-207. 
Fiss, P.C. (2011), "Building better causal theories: a fuzzy set approach to typologies in organization research", The Academy of Management Journal, Vol. 54 No. 2, pp. 393420.

Fu, X., Chen, X., Shi, Y.-T., Bose, I. and Cai, S. (2017), "User segmentation for retention management in online social games”, Decision Support Systems, Vol. 101, pp. 51-68.

Fu, X. and Lehto, X. (2018), "Vacation Co-creation: The Case of Chinese Family Travelers", International Journal of Contemporary Hospitality Management, Vol. 30 No. 2, pp. 980-1000.

Gardner, R.O. (2004), “The portable community: mobility and modernization in bluegrass festival life", Symbolic Interaction, JSTOR, Vol. 27 No. 2, pp. 155-178.

Getz, D. (2012), "Event studies: discourses and future directions", Event Management, Vol. 16 No. 2, pp. 171-187.

Giraldo Oliveros, M.E. (2015), Value Creation and Social Context in Service Encounters: A Practice Approach, University of Surrey.

Goulding, C., Shankar, A. and Canniford, R. (2013), "Learning to be tribal: facilitating the formation of consumer tribes", European Journal of Marketing, Vol. 47 No. 5/6, pp. 813-832.

Grissemann, U.S. and Stokburger-Sauer, N.E. (2012), "Customer co-creation of travel services: the role of company support and customer satisfaction with the co-creation performance", Tourism Management, Vol. 33 No. 6, pp. 1483-1492.

Grönroos, C. and Voima, P. (2013), “Critical service logic: making sense of value creation and co-creation”, Journal of the Academy of Marketing Science, Vol. 41 No. 2, pp. 133150.

Heinonen, K. and Strandvik, T. (2015), “Customer-dominant logic: foundations and implications", Journal of Services Marketing, Vol. 29 No. 6/7, pp. 472-484.

Heinonen, K., Strandvik, T. and Voima, P. (2013), "Customer dominant value formation in service”, European Business Review, Vol. 25 No. 2, pp. 104-123.

Hoek, J., Gendall, P. and Esslemont, D. (1996), "Market segmentation: A search for the Holy Grail?”, Journal of Marketing Practice: Applied Marketing Science, Vol. 2 No. 1, pp. $23-25$. 
Holt, D.B. (1995), "How consumers consume: a typology of consumption practices”, Journal of Consumer Research, JSTOR, Vol. 22 No. 1, pp. 1-16.

Holttinen, H. (2010), "Social practices as units of value creation: theoretical underpinnings and implications", International Journal of Quality and Service Sciences, Vol. 2 No. 1, pp. 95-112.

Horbel, C., Popp, B., Woratschek, H. and Wilson, B. (2016), "How context shapes value cocreation: spectator experience of sport events", The Service Industries Journal, Routledge, Vol. 36 No. 11-12, pp. 510-531.

Kim, H. and Jamal, T. (2007), "Touristic quest for existential authenticity”, Annals of Tourism Research, Elsevier Science, Vol. 34 No. 1, pp. 181-201.

Kim, K., Byon, K.K. and Baek, W. (2019), "Customer-to-customer value co-creation and codestruction in sporting events", The Service Industries Journal, Routledge, pp. 1-23.

Kim, S.Y., Jung, T.S., Suh, E.H. and Hwang, H.S. (2006), “Customer segmentation and strategy development based on customer lifetime value: A case study", Expert Systems with Applications, Vol. 31 No. 1, pp. 101-107.

Kjellberg, H., Nenonen, S. and Marini Thomé, K. (2018), “Analyzing service processes at the micro level: actors and practices", in Vargo, S. and Lusch, R. (Eds.), The SAGE Handbook of Service-Dominant Logic, Sage Publications, London, pp. 411-430.

Knox, S. (1998), "Loyalty-based segmentation and the customer development process", European Management Journal, Vol. 16 No. 6, pp. 729-737.

Kotler, P. and Keller, K.L. (2012), Marketing Management, 14th ed., Pearson Education, Harlow.

Luo, J., Wong, I.A., King, B., Liu, M.T. and Huang, G. (2019), “Co-creation and codestruction of service quality through customer-to-customer interactions: Why prior experience matters", International Journal of Contemporary Hospitality Management, Emerald, Vol. 31 No. 3, pp. 1309-1329.

Mackellar, J. (2009a), “An examination of serious participants at the Australian Wintersun Festival”, Leisure Studies, Routledge, Vol. 28 No. 1, pp. 85-104.

Mackellar, J. (2009b), "Dabblers, fans and fanatics: Exploring behavioural segmentation at a special-interest event”, Journal of Vacation Marketing, Vol. 15 No. 1, pp. 5-24. 
McColl-Kennedy, J.R., Vargo, S.L., Dagger, T.S., Sweeney, J.C. and van Kasteren, Y. (2012), "Health care customer value cocreation practice styles", Journal of Service Research, Vol. 15 No. 4, pp. 370-389.

McPherson, M., Smith-Lovin, L. and Cook, J.M. (2001), "Birds of a feather: homophily in social networks", Annual Review of Sociology, Vol. 27 No. 1, pp. 415-444.

Oliver, R.L. (1999), “Whence consumer loyalty?”, The Journal of Marketing, JSTOR, Vol. 63 No. Special Issue 1999, pp. 33-44.

Parker, C. and Ward, P. (2000), “An analysis of role adoptions and scripts during customerto-customer encounters", European Journal of Marketing, Emerald Group Publishing Ltd, Vol. 34 No. 3/4, pp. 341-359.

Pine, B.J.I.I., Peppers, D. and Rogers, M. (2010), "Do you want to keep your customers forever?", Harvard Business Review, Harvard Business Press, Vol. 73 No. March/April, pp. 103-114.

Pongsakornrungsilp, S. and Schroeder, J.E. (2011), "Understanding value co-creation in a coconsuming brand community", Marketing Theory, Vol. 11 No. 3, pp. 303-324.

Prahalad, C.K. and Ramaswamy, V. (2004), "Co-creating unique value with customers", Strategy and Leadership, Vol. 32 No. 3, pp. 4-9.

Prebensen, N.K. and Foss, L. (2011), “Coping and co-creating in tourist experiences", International Journal of Tourism Research, John Wiley \& Sons, Ltd., Vol. 13 No. 1, pp. 54-67.

Quinn, L. and Dibb, S. (2010), “Evaluating market-segmentation research priorities: Targeting re-emancipation", Journal of Marketing Management, Vol. 26 No. 13-14, pp. $1239-1255$.

Quinn, L., Hines, T. and Bennison, D. (2007), "Making sense of market segmentation: a fashion retailing case”, European Journal of Marketing, Vol. 41 No. 5/6, pp. 439-465.

Ragin, C. (2008), Redisigning Social Inquiry: Fuzzy Sets and Beyond, The University of Chicago Press, Chicago, IL.

Rantala, O. (2010), "Tourist practices in the forest", Annals of Tourism Research, Vol. 37 No. 1, pp. 249-264.

Reckwitz, A. (2002), "Toward a theory of social practices: a development in culturalist 
theorizing”, European Journal of Social Theory, Vol. 2 No. 2, pp. 243-263.

Reichenberger, I. (2017), "C2C value co-creation through social interactions in tourism", International Journal of Tourism Research, Vol. 19 No. 6, pp. 629-638.

Rihova, I., Buhalis, D., Gouthro, M.B. and Moital, M. (2018), “Customer-to-customer cocreation practices in tourism: Lessons from Customer-Dominant logic", Tourism Management, Vol. 67, pp. 362-375.

Rosenbaum, M.S. (2008), "Return on community for consumers and service establishments", Journal of Service Research, Vol. 11 No. 2, pp. 179-196.

Russo-Spena, T. and Mele, C. (2012), “'Five Co-s' in innovating: a practice-based view”, Journal of Service Management, Vol. 23 No. 4, pp. 527-553.

Ryan, C. (2012), "The experience of events", in Page, S.J. and Connell, J. (Eds.), The Routledge Handbook of Events, Routledge, Abingdon, pp. 248-259.

Sausen, K., Tomczak, T. and Herrmann, A. (2005), "Development of a taxonomy of strategic market segmentation: a framework for bridging the implementation gap between normative segmentation and business practice", Journal of Strategic Marketing, Vol. 13 No. 3, pp. 151-173.

Schatzki, T.R. (1996), Social Practices: A Wittgensteinian Approach to Human Activity and the Social, Cambridge University Press, Cambridge.

Schatzki, T.R. (2001), "Introduction: practice theory”, in Schatzki, T.R., Cetina, K.K. and Savigny, E. von (Eds.), The Practice Turn in Contemporary Theory, Routledge, New York, NJ, pp. 10-23.

Schau, H.J., Muñiz Jr, A.M. and Arnould, E.J. (2009), "How brand community practices create value", Journal of Marketing, Vol. 73 No. 5, pp. 30-51.

Simkin, L. (2016), “Segmentation”, in Baker, M.J. and Hart, S. (Eds.), The Marketing Book, 7th ed., Routledge, New York, NY, pp. 271-294.

Sinha, P.K. and Uniyal, D.P. (2005), "Using observational research for behavioural segmentation of shoppers", Journal of Retailing and Consumer Services, Vol. 12 No. 1, pp. 35-48.

Skaaning, S.-E. (2011), “Assessing the Robustness of Crisp-set and Fuzzy-set QCA Results”, Sociological Methods \& Research, Vol. 40 No. 2, pp. 391-408. 
Snellman, K. (2000), "From one segment to a segment of one: the evolution of market segmentation theory", Hanken Swedish School of Economics and Business Administration Working Papers, Swedish School of Economics and Business Administration, Helsinki, available at: https://helda.helsinki.fi/handle/10227/128.

Sorensen, A. and Drennan, J. (2017), “Understanding value-creating practices in social media-based brand communities", The Service Industries Journal, Routledge, Vol. 37 No. $15-16$, pp. 986-1007.

Storbacka, K. (1997), "Segmentation based on customer profitability — retrospective analysis of retail bank customer bases", Journal of Marketing Management, Vol. 13 No. 5, pp. $479-492$.

Strauss, A.L. and Corbin, J.M. (1990), Basics of Qualitative Research: Grounded Theory Procedures and Techniques, Sage Publications, London.

Tajfel, H. (1982), Social Identity and Intergroup Relations, Cambridge University Press, Cambridge.

Tonks, D.G. (2009), "Validity and the design of market segments", Journal of Marketing Management, Vol. 25 No. 3-4, pp. 341-356.

Tu, Y., Neuhofer, B. and Viglia, G. (2018), "When co-creation pays: stimulating engagement to increase revenues", International Journal of Contemporary Hospitality Management, Emerald, Vol. 30 No. 4, pp. 2093-2111.

Turner, V. (1995), The Ritual Process: Structure and Anti-Structure (with a Foreword by Roger D. Abrahams), The Lewis Henry Morgan Lectures, Aldine de Gruyter, New York, NJ.

Vargo, S.L. and Lusch, R.F. (2016), "Institutions and axioms: an extension and update of service-dominant logic", Journal of the Academy of Marketing Science, Vol. 44 No. 1, pp. 5-23.

Vargo, S.L. and Lusch, R.L. (2004), "Evolving to a new dominant logic for marketing", Journal of Marketing, American Marketing Association, Vol. 68 No. 1, pp. 1-17.

Vargo, S.L. and Lusch, R.L. (2008), "Service-dominant logic: continuing the evolution”, Journal of the Academy of Marketing Science, Springer Netherlands, Vol. 36 No. 1, pp. $1-10$. 
Viljoen, A., Kruger, M. and Saayman, M. (2017), “The 3-S typology of South African culinary festival visitors", International Journal of Contemporary Hospitality Management, Emerald, Vol. 29 No. 6, pp. 1560-1579.

Wedel, M. and Kamakura, W. (2002), "Introduction to the special issue on market segmentation”, International Journal of Research in Marketing, Vol. 19 No. 3, pp. 181183.

Wedel, M. and Kamakura, W.A. (2000), Market Segmentation: Conceptual and Methodological Foundations, edited by Eliashberg, J.International Series in Quantitative Marketing, 2nd ed., Kluwer Academic Publishers, Norwell, MA.

Weinstein, A. (2002), "Customer retention: A usage segmentation and customer value approach", Journal of Targeting, Measurement and Analysis for Marketing, Vol. 10 No. 3, pp. 259-268.

Wilks, L. (2011), "Bridging and bonding: social capital at music festivals", Journal of Policy Research in Tourism, Leisure and Events, Routledge, Vol. 3 No. 3, pp. 281-297.

Yngfalk, A.F. (2013), “'It's not us, it's them!' - Rethinking value cocreation among multiple actors", Journal of Marketing Management, Vol. 29 No. 9-10, pp. 1163-1181. 